\title{
How to Increase the Income of Peasants: Anti-poverty Effect of Agricultural Products Brands
}

\author{
Jinsong Chen ${ }^{1}$, Hexiang Wang ${ }^{1 *}$ \\ ${ }^{1}$ Business Administration School of Guizhou University of Finance and Economics, Guiyang, Guizhou, China
}

\begin{abstract}
The advancement of agricultural product brands has a significant role in promoting local economic and social development. Through analysis, it can be seen that there keeps still a lot of room for improvement of agricultural products brands in terms of economic driving. To realize the coupling of agricultural product brands and rural revitalization, it is necessary to make up for the shortcomings of agricultural product brands and poverty alleviation of poverty, cultivate characteristic industrial parks, optimize agricultural product value chains, improve brand supervision, and strengthen e-commerce talent training, so as to achieve agricultural product brand building organic connection with agricultural and rural modernization as well as increase the income of peasants.
\end{abstract}

\section{Introduction}

The agricultural issue has always been one of the major issues in the development of human society. As the core symbol of agricultural modernization [1], branding of agricultural products is an important means to solve the problem of lagging agricultural development and unsalable agricultural products in backward areas, and it is also an effective way to promote agricultural income growth ${ }^{[2]}$. Research has found that brand is an important way to improve product competitiveness ${ }^{[3]}$ and can expand the market influence of products ${ }^{[4]}$. Brands have an income-increasing effect on farmers' economic income [5].

A review of relevant literature found that agricultural product brand building and anti-poverty content have been studied in depth, and people have realized the importance of agricultural product brands to economic development. However, most of the previous literatures focused on agricultural product brand building or unilateral research on anti-poverty. Some scholars combine agricultural product brands with anti-poverty, agricultural and rural modernization and other content, and have less involvement in the positive role of agricultural product brands in rural revitalization. In view of this, this article will conduct research from this aspect, which will not only help enrich the existing research fields, but also provide new ideas for the local government to prevent poverty and realize the modernization of agriculture and rural areas.

\section{Agricultural product brands and the status quo of agricultural income}

\subsection{Increasing brand awareness and increasing farmers' income}

In recent years, countries have paid more and more attention to the development of agricultural branding. In the process of vigorously implementing the brand strategy, aiming at problems such as unclear brand positioning, weak brand awareness and protection, low brand equity, etc., through measures such as improving the reward mechanism, setting up brand special funds, and improving brand supervision, it is the brand of the anti-poverty industry. The construction provides a strong supporting force. On the other hand, regional pillar enterprises continue to increase their efforts in regional brand building. While maintaining regional brands, they have achieved brand innovation and development by upgrading their concepts of competition and building contract alliances, thereby enhancing the core competitiveness of the anti-poverty industry.

Taking Guizhou, China as an example, with the joint efforts of the central and local governments and regional pillar enterprises, the brand awareness of agricultural products in Guizhou Province has increased significantly, which has actively promoted farmers' income. Taking the top three agricultural regional public brands in Guizhou Province as an

*Corresponding author: wanghx96@yeah.net 
example, their brand value has increased year by year, as shown in Figure $1^{\oplus}$.

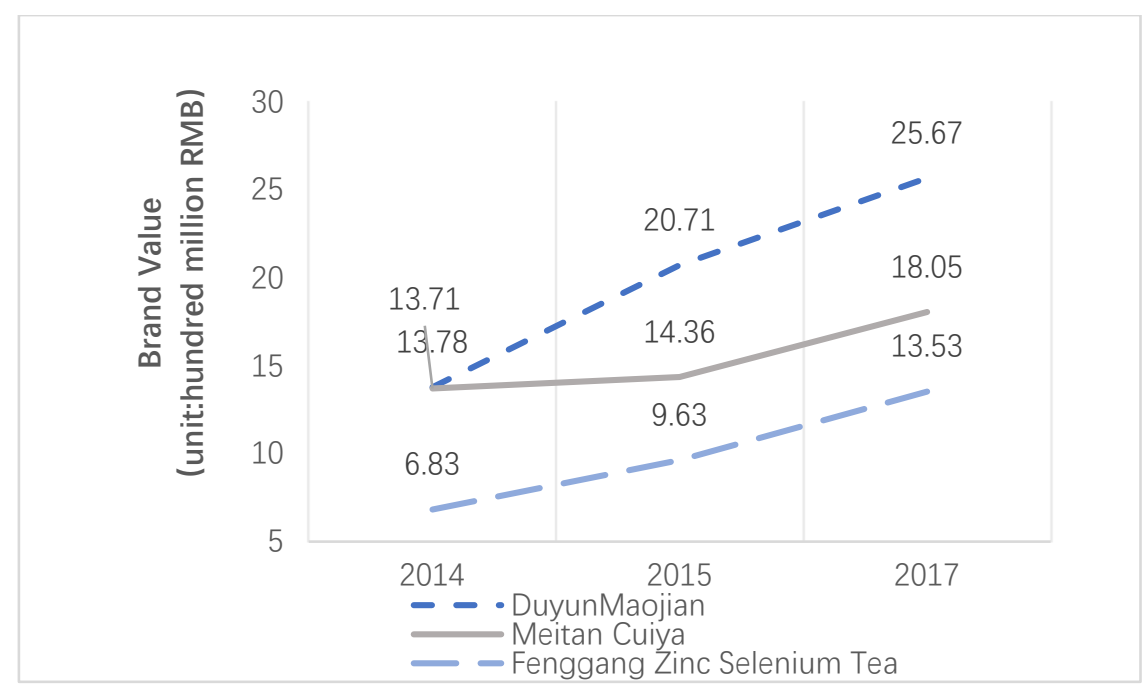

Fig. 1. Regional public brand value of the top three agricultural products in Guizhou Province

(2014-2017)

\subsection{Effective connection of branded agriculture and urban-rural integration development}

With the strong support of the government, various regions have actively organized agricultural product brand certification activities in accordance with local conditions, and selected famous brands, organic product certification, and agricultural geographical indications. In addition, by holding cultural tourism festivals and expositions, while promoting local characteristic national culture, all regions have made full use of opportunities such as expositions and key festivals to launch special agricultural products, and use cross-border e-commerce platforms to strengthen agricultural trade cooperation with overseas markets, and realize branded agriculture. With the simultaneous development of the antipoverty industry, brand agriculture and the antipoverty industry have been effectively connected. Taking the tea in Guizhou, China as an example, in the top 100 national tea regional public value lists in 2020 , there are a total of 4 tea regional public brands in Guizhou Province on the list, and their brand values have increased compared with 2019, as shown in Table $1^{2}$.

Table 1 Guizhou Province Tea Regional Public Brand Value (Top 100)

\begin{tabular}{cccc}
\hline Brand Name & Years & Rank & $\begin{array}{c}\text { Brand Value } \\
\text { (hundred million RMB) }\end{array}$ \\
\hline Duyun Maojian & 2019 & 11 & 32.90 \\
& 2020 & 10 & 35.28 \\
Fanjing Camellia & 2019 & 31 & 23.4 \\
& 2020 & 29 & 26.2 \\
Fenggang Zinc & 2019 & 42 & 19.57 \\
Selenium Tea & 2020 & 39 & 22.96 \\
Yuqing Kuding & 2019 & 91 & 4.87 \\
Tea & 2020 & 88 & 4.89 \\
\hline
\end{tabular}

\section{Problems of agricultural products brands and agricultural income}

\subsection{Lack of a complete brand building and funding mechanism for poverty alleviation of the poor}

\footnotetext{
${ }^{1}$ Source: According to the data of China Agricultural Brand Research Center.
}

Agricultural investment has a very significant positive impact on peasants' income, and has the effect of continuously driving peasants' income ${ }^{[6]}$. It can be seen from the development status of agricultural products brands that the number and economic value of agricultural products brands are increasing year by year, but in terms of income increase, the effectiveness needs to be improved, the main reason is the shortage of funds. Most of the

\footnotetext{
2. Source: According to the data of China Agricultural Brand Research Center.
} 
production and operation entities of agricultural products are mainly based on a dispersed population. The agricultural products sold on the product market are relatively scattered and have a high degree of homogeneity. Coupled with the shortage of funds, there are few well-known regional agricultural products brands on the market. At this stage, there are many agricultural subsidies issued by the central government, but there is little mention of agricultural product brand building funds directly. Many agricultural product producers want to build agricultural product brands, often because of the shortage of funds, they "have more than enough energy".

\subsection{The brand marketing effect remains ineffective, and the industry anti-poverty effect keeps stagnant}

At present, the shortcomings of agricultural product brand marketing mainly reflect the following aspects: Firstly, a systematic brand marketing concept has not yet been formed. Certain factors of agricultural product producers, such as limited education and lack of development awareness, have seriously affected the development of brand agriculture. In the business process, even if a product brand is established, the focus is more on the sales and income of agricultural products, and the sustainable development direction such as brand marketing is rarely considered. Despite the government's support, the market efficiency is still low, and the industry's anti-poverty performance is greatly reduced. Secondly, the marketing method is traditional, single, and lacks innovation. The limitation of its own strength and the unknown marketing effect make agricultural product operators more inclined to invest limited resources into the normal agricultural product life cycle.

\subsection{E-commerce talents are scarce, and brand anti-poverty effects are weakened}

The current agricultural e-commerce development is facing the problem of industry development and lack of talents. According to statistics, nearly $80 \%$ of China's ecommerce companies have a shortage of talents ${ }^{3}$, and the rural e-commerce talent gap will reach 3.5 million in $2025^{4}$. Although colleges and universities have set up ecommerce-related majors, the e-commerce talent reserve of the whole society is still in a state of scarcity ${ }^{[7]}$. Even if the development of countrys' agricultural product ecommerce has gradually matured in recent years, the future development of the entire industry will need to rely on a new generation of high-end information technology talents such as big data and artificial intelligence. Green agricultural product e-commerce anti-poverty needs are compound talents who understand both the Internet industry and agriculture, and integrate professional skills and management skills to operate and manage.

\footnotetext{
(3) Source: Net Economics E-commerce Research Center, "2019 China E-commerce Talent Survey Report".
}

\section{Improving the anti-poverty effect of agricultural product brands}

\subsection{Give full play to the leading role of the government to make up for shortcomings}

As is known to all, it is necessary to play the leading role of public organizations to improve the brand building of agricultural products. The government should also increase the scale of investment in agricultural product brand building, such as implementing tax reductions, agricultural subsidies, so as to achieve the innovative development of agricultural product brands. In Japan, it is due to the continuous high government subsidies that have enhanced the core competitiveness of Japanese agricultural products brands. Therefore, we should actively learn from the experience of agricultural products construction in developed agricultural countries such as Japan, and provide corresponding policy and financial support to core agriculturalrelated enterprises in combination with the financial capabilities of various regions, so as to supplement agricultural product brand building and capital investment in increasing farmers' income are shortcomings.

\subsection{Cultivating characteristic industrial parks and enhancing brand marketing effects}

At present, some well-known "Qianhuo" brands have appeared on the market, such as Duyun Maojian, Meitan Cuiya and Dafang Tianma, etc. However, these brands account for a relatively small share of the national regional agricultural product brand market. Compared with a single product producer, the scale advantage of agricultural parks can play a greater role in the brand marketing process. Therefore, it is necessary to achieve scale effects.

First of all, comprehensively considering local agricultural resources to achieve innovative development of characteristic industries. Relevant departments should formulate a modern industrial park plan for characteristic agricultural products, clarify the leading industries, and provide sufficient financial support. Next, firms and government are subject to strengthen industrial collaboration. Forming an industrial collaboration circle centered on leading industries, improving supporting industries, and realizing a highly concentrated and closely connected upstream and downstream industrial chain. Afterwards, clarifying the leading enterprises. Leading enterprises are the representatives of the comprehensive

\footnotetext{
Source: China Agricultural University Smart Ecommerce Research Institute, "2020 China Rural Ecommerce Talent Status and Development Report".
} 
competitiveness of industrial parks, playing a leading role in the brand marketing process, and playing a key role in achieving economies of scale.

\subsection{Strengthening the training of e-commerce talents and improving the anti-poverty effect}

With the advancement of the e-commerce industry, society has put forward new requirements for the quantity and quality of e-commerce talents. Rural e-commerce sales talents need to master the operating skills of various e-commerce digital service platforms, and be able to analyse the supply and demand information of agricultural products market ${ }^{[8]}$. Therefore, we must shed light on the cultivation of rural e-commerce talents, strengthen professional quality education and practical training, and provide an inexhaustible source of talents for agricultural product brand communication.

Clarifying the training goals of rural e-commerce talents. Currently, e-commerce of agricultural products has an urgent need for talents in logistics management, product design and operation, and online sales. Furthermore, increasing the intensity of professional knowledge training. Agricultural product e-commerce needs not only technical personnel who understand new media operations, but also professionals who understand agricultural product e-commerce. Last but not least, strengthening school-enterprise cooperation. Providing students with more internship opportunities and improve the efficiency of talent training.

\section{Conclusion}

Essentially, the anti-poverty effect of agricultural products brands is worthy of recognition, which is obvious in various regions. However, we can find that this rate of increase in revenue is relatively moderate. Therefore, we must give full play to the anti-poverty effect of agricultural products brands in the future: First, from the government level, it is necessary to vigorously promote brand strategies, strengthen information exchanges between departments, avoid opportunistic behaviors of agricultural product producers and sellers, and eliminate causes. The phenomenon of agricultural product brand formalism caused by interest relations gives play to the incomeincreasing effect of agricultural product brands in the antipoverty process. And then, firms ought to strengthen the potential innovation passion of agricultural products producers as well as sellers' markets, and product quality supervision to ensure the rapid and effective completion of agricultural products transactions and accelerate the realization of agricultural and rural modernization.

\section{Acknowledgements}

This article is one of the periodic results of the National Natural Science Foundation project "Research on the Tolerance and Reaction Strategy of Marketing Channel Boundary Personnel to Opportunistic Behavior" (71562003).

\section{References}

1. Lu Lige, Lu Guangli, Gao Ru. (2020)Evaluation and Improvement of Brand Communication Power of Agricultural Products in County Area. Journal of Northwest A \& F University (Social Science Edition),20:154-160.

2. Dong Yaning, Gu Yun, Yang Kaizhong. (2021) Brands of agricultural products, market integration and agricultural income growth. Journal of Capital University of Economics and Business, 23:70-80.

3. Aaker,D.A.(1992)Managing Brand Equity: Capitalizing on the Value of a Brand Name. Journal of Marketing, 56:125-128.

4. Martinovic, Stjepo.(2002)Branding Hrvatska--a mixed blessing that might succeed: The advantage of being unrecognizable. Journal of Brand Management,9:315-322.

5. Ohe,Y,Kurihara,S.(2013)Evaluating the complementary relationship between local brand farm products and rural tourism: Evidence from Japan. Tourism management, 35:278-283.

6. Zhao Yongzhi, Luo Erga, Li Jianping. (2019) The impact of comprehensive agricultural development investment on farmers' incomebased on China's provincial panel data. China Rural Economy, 5: 22-37.

7. Yan Qiang, Wang Guoli, Chen Jiayou.(2018) The path and countermeasures for precision anti-poverty of agricultural product ecommerce-Taking the poor rural areas of Guizhou as an example. Rural Economy, 2:4551.

8. Song Dongmei.(2018)The the development of rural e-commerce clusters and the cooperative training of e-commerce talents. Agricultural Economics, 12:129-131. 